\title{
INNOVATION AND PERFORMANCE: AN ANALYSIS OF SUSTAINABLE FIRMS IN BRAZIL
} AND EUROPE

\section{INOVAÇÃO E DESEMPENHO: UMA ANÁLISE DE EMPRESAS SUSTENTÁVEIS DO BRASIL E DA EUROPA}

\section{INOVACIÓN Y DESEMPEÑO: UN ANÁLISIS DE EMPRESAS SUSTENTABLES DE BRASIL Y EUROPA}

Recebido em: 21/05/2018

Avaliado em: 26/08/2018

Reformulado em:08/09/2018

Aceito para publicação em: 13/09/2018

Publicado em: 30/11/2019

Editor Responsável: Moacir M. Rodrigues Junior
José Glauber Cavalcante dos Santos ${ }^{1}$

Alessandra Carvalho de Vasconcelos ${ }^{2}$

Márcia Martins Mendes De Luca ${ }^{3}$

Jacqueline Veneroso Alves da Cunha ${ }^{4}$

\section{ABSTRACT}

In this study we analyze whether the innovation profile of sustainable Brazilian and European firms produces a difference in economic performance. Resource-Based View (RBV) posits that innovation, due to uniqueness and heterogeneity, leads to competitive advantage and improved performance. Data was collected from 78 sustainable firms covering the period 2010-2013 and analyzed with the MannWhitney test and the Kruskal-Wallis test. Four perspectives on innovation were considered: R\&D, intangible innovation assets, patents, and disclosure. Economic performance was expressed as return on assets and return on equity. Innovation contributed to superior performance (though not significantly), but the claim that innovation generates competitive advantage could not be validated. Our results suggest the existence of a hypothetical curve of efficiency determined by diversification of innovation since higher levels of innovation were not necessarily related with greater performance. This may be explained by the assumption of heterogeneity, according to RBV. The study provides subsidies for managers looking to optimize investments in innovation, increasing the efficiency of resources and boosting differentiation in different economic scenarios.

Keywords: Innovation; Performance; Resource-based view.

\section{RESUMO}

Essa pesquisa analisa se o perfil da inovação em firmas brasileiras e europeias sustentáveis gera diferenças no desempenho econômico. O arcabouço teórico da visão da firma baseada em recursos

\footnotetext{
1 Doutorando em Administração e Controladoria pela Universidade Federal do Ceará (UFC); E-mail: jglauber_cont@hotmail.com

${ }^{2}$ Doutora em Engenharia de Produção pela Universidade Federal de Santa Catarina (UFSC); Professora da Universidade Federal do Ceará (UFC); E-mail: alevasconcelos.ufc@ gmail.com

3 Doutora em Controladoria e Contabilidade pela Universidade de São Paulo (USP); Professora Associada da Universidade Federal do Ceará (UFC); E-mail: marciadeluca@ufc.br

${ }^{4}$ Doutora em Controladoria e Contabilidade pela Universidade de São Paulo (USP Professora Associada da Universidade Federal de Minas Gerais (UFMG); E-mail: jvac@ face.ufmg.br
} 
sugere que a inovação, devido a sua singularidade e heterogeneidade, está relacionada com a construção de vantagens competitivas e melhoria do desempenho. A análise compreende 78 empresas, com dados alusivos ao período de 2010 a 2013, aplicados testes de Mann-Whitney e Kruskal-Wallis. A inovação foi avaliada sob quatro perspectivas, investimentos em Pesquisa e Desenvolvimento (P\&D), ativos intangíveis de inovação, patentes registradas e divulgação; o desempenho econômico, por sua vez, foi medido através do retorno dos ativos e do patrimônio líquido. Os resultados apontam que a inovação não consegue configurar vantagens competitivas entre as firmas, podendo, todavia, contribuir para a obtenção de desempenho superior. O estudo revela ainda, que pode haver uma curva hipotética de eficiência com relação à diversificação da inovação, pois maiores níveis de inovação não necessariamente implicam em desempenho médio superior, como sugere a pressuposição teórica da heterogeneidade, segundo a visão da firma baseada em recursos. $\mathrm{O}$ estudo contribui à identificação de oportunidades eficientes de investimento em inovação em firmas de distintas economias.

Palavras-chave: Inovação; Desempenho; Visão da firma baseada em recursos.

\section{RESUMEN}

Este estudio examina si el perfil de la innovación en firmas brasileñas y europeas sustentables genera diferencias en su desempeño económico. El andamiaje teórico de la visión de la firma basada en recursos sugiere que la innovación, debido a su singularidad y heterogeneidad, está relacionada con la construcción de ventajas competitivas y la mejora del desempeño. El análisis comprende 78 empresas, con datos alusivos al período de 2010 a 2013, aplicadas pruebas de Mann-Whitney y Kruskal-Wallis. La innovación fue evaluada bajo cuatro perspectivas: inversiones en Investigación y Desarrollo (P\&D), activos inalcanzables de innovación, patentes registradas y divulgación. El desempeño económico, por su parte, fue medido a través del retorno de los activos y del patrimonio líquido. Los resultados señalan que la innovación no logra configurar ventajas competitivas entre las firmas, pudiendo, sin embargo, contribuir para la obtención de desempeño superior. El estudio revela además, que puede haber una curva hipotética de eficiencia con relación a la diversificación de la innovación, pues mayores niveles de innovación no necesariamente implican desempeño medio superior, como sugiere la presuposición teórica de la heterogeneidad, según la visión de la firma basada en recursos. El estudio contribuye a la identificación de oportunidades eficientes de inversión en innovación en firmas de distintas economías.

Palabras clave: Innovación; Desempeño; Visión de la firma basada en recursos.

\section{INTRODUCTION}

Innovation may be used by firms to build competitive advantage by expanding activities and boosting economic performance, thereby reducing the risk of non-permanence on the market (Freeman, \& Soete, 2008; Schumpeter, 1988; Teigland, Fey, \& Birkinshaw, 2000; Tidd, Bessant, \& Pavitt, 2008). This is the assumption underlying the discussion on the ability of organizational differentiation to create heterogeneity in performance. In other words, the nature of the resources controlled by firms, their competences and accumulated know-how are the main determinants of corporate differentiation (Hart, 1995; Barney, 1991). Expenditure on innovation involving the development of new or redesigned products may be considered a potential opportunity for future economic benefits. However, because benefits from investment in innovation are difficult to predict, such expenditure is characterized by high levels of uncertainty (Gonçalves, \& Lemes, 2018).

Consequently, investors with short-term goals tend to underestimate firms which focus on innovation. This is due to difficulties in assessing less tangible accounting information, such as expenditure on innovation (Songur, \& Heavilin, 2017). 
According to Resource-Based View (RBV), to attain sustained competitive advantage, strategic resources should be valuable, rare and difficult to imitate, replicate or substitute (Barney, 1991). As a strategic resource, innovation-the main construct of the present study-potentially possesses all these qualities, making it essential to successful economic activity and justifying investigations of the association between innovation and performance.

On the other hand, firms are increasingly under pressure from stakeholders to adopt management models based on sustainable strategic proposals. The concept of sustainability has greatly impacted local and global sociocultural and economic reality and has acquired a status similar to that of innovation: sustainability is now itself a competitive advantage essential to business (Barbieri et al., 2010; Barbieri, 2013; Bhandari, \& Javakhadze, 2017; Carvalho, Heikkurinen, \& Bonnedahl, 2013; González-Benito, \& González-Benito, 2006; Hart, 1995; Heikkurinen, \& Bonnedahl, 2013; Middleton, 2015; Santos, \& Porto, 2013).

The combination of innovation and sustainability in the building of competitive advantage is a challenge firms have to tackle to preserve their market share. Firms have to regularly introduce new products on the market in order to raise competitive barriers and therefore, in light of RBV, resort to innovation. On the other hand, the market expects firms to adopt and adhere to the latest set of sustainable practices. According to Silvestre and Țîrcă (2019), the combination of the strategies of innovation and sustainability is a relatively new and complex undertaking, requiring significant corporate restructuring in terms of products, processes, policies, supply chains and management models.

The concomitance of the two strategic outlooks, or even their synergy, provides an opportunity for firms to identify the best alternatives for sustained differentiation and superior performance in the quest for excellence (Barbieri et al., 2010). Gomes et al. (2013), Khurana, Haleem and Mannan (2019) and Silvestre and Ţîrcă (2019) add that competitiveness is increasingly dependent on investments in both innovation and sustainability, lending support to the theories of Barney (1991) and Hart (1995) and to RBV.

Based on RBV, firms in possession of strategic resources (in this case, innovation) and the organizational structure required to exploit it will obtain competitive advantage, resulting in improved performance (Carvalho, Kayo, \& Martin, 2010). However, studies monitoring the association between innovation and performance have yielded inconsistent results, with some describing the correlation as positive, some as negative, and some as non-significant (Baaij, Greeven, \& Van Dalen, 2004; Blundell, Griffiths, \& Van Reenenl, 1999; Brito, Brito, \& Morganti, 2009; Carvalho, Kayo, \& Martin, 2010; Jefferson et al., 2003; Jesen, Menezes-Filho, \& Sbragia, 2004; Lee, \& Chen, 2009; Perez, \& Famá, 2006; Samad, 2012; Santos et al., 2014; Silveira, \& Oliveira, 2013; Songur, \& Heavilin, 2017; The, Kayo, \& Kimura, 2008)

To Brito, Brito and Morganti (2009), the conceptual relation between innovation and performance is not in question, despite the difficulty in providing empirical evidence for it. Inconsistent results may be explained by the demand for conditions under which innovation, as a unique strategic resource, can generate competitive advantage and, consequently, boost performance (Barney, 1991). In the present study we evaluated the contribution of innovation to economic performance in firms considered sustainable and attempted to determine whether sustainability is one such condition, as suggested by Gomes et al. (2013) and Kim (2015).

Few studies have documented the effect of innovation on corporate performance in sustainable firms. In fact, recent investigations have mostly focused on the connection between innovation and sustainability, with many authors arguing that sustainable practices are the result of an innovative profile (Abbas, \& Sağsan, 2019; Albert, 2019; Busco, \& Quattrone, 2018; Gomez-Conde, Lunkes, \& Rosa, 2018; Silvestre, \& Țîrcă 2019). Our study analyzes whether the innovation profile of sustainable Brazilian and European firms produces a difference in economic performance. Four criteria were used to classify firms as innovative: i) investment in R\&D ("inputs"), ii) intangible assets of innovation, iii) patents filed by the firm ("outputs"), and iv) disclosure of information about the 
firm's innovative activities. Performance was quantified based on profitability: i) return on assets (ROA), and ii) return on equity (ROE). The sample consisted of 78 industrial firms awarded one or more of the following sustainability grades: i) Index of Corporate Sustainability (ISE), ii) Index of Carbon Efficiency (ICO2), and iii) Low Carbon 100 Europe Index (the first two awarded by B3, the third awarded by NYSE Euronext). Our data covered a period of four years (2010-2013).

The investigation is intended as a subsidy for both academic and managerial audiences interested in the sustainability and innovation profiles of companies as strategic resources capable of boosting economic performance.

The results of this study contribute to the development of innovative activities, based on the criterion of economic efficiency of resources, in firms regarded as sustainable in their respective markets. Regarded as an opportunity to boost future economic performance, though at high levels of risk and uncertainty (Rajapathirana, \& Hui, 2018; Salimi, \& Rezaei, 2018; Silvestre, \& Țîrcă, 2019), innovation asserts itself as a managerial element pertinent to corporate perpetuation.

It is the task of corporate management to assess the financing and destination of resources associated with innovative activities characterized by complexity and uncertain returns. As for the practical implications of the study, our results may subsidize corporate decision making considering that innovation and sustainability to a large extent reflect the economic and financial structure of the firm and may be relevant to investors on the capital market (Bhandari, \& Javakhadze, 2017; Jiang, \& Stark, 2013; Madorran, \& Garcia, 2016; Middleton, 2015; Silvestre, \& Țîrcă, 2019).

In addition, since the innovative profile and sustainable practices of a firm are seen by the market as a sign of future opportunities or economic costs, our study can help managers and accountants make disclosure more relevant to investors and target potential information users more efficiently (Jiang, \& Stark, 2013; Lys, Naughton, \& Wang, 2015; Middleton, 2015; Gonçalves, \& Lemes, 2018).

\section{THEORETICAL BACKGROUND: INNOVATION, PERFORMANCE AND SUSTAINABILITY}

According to Barney (1991), RBV is based on two assumptions: i) firms are heterogeneous with regard to the strategic resources they control, and ii) strategic resources are not easily transferred to other firms, justifying the perpetuation of heterogeneity over extended periods. Thus, the uniqueness of resources and the leading position of a given firm on the market depend primarily on corporate efforts to mobilize and harness assets capable of aggregating value and competitive advantage.

RBV allows to identify and group resources with which firms can create position barriers. By employing resource position barriers, firms can stay ahead of the competition and consolidate their leadership on the market. This is made possible by the properties and mode of acquisition of each resource. In short, firms strive to attain an advantage which, by virtue of the uniqueness of the resources employed, is near-impossible to be replicated by competitors (Wernerfelt, 1984).

Likewise, Peteraf (1993) stresses that RBV is essentially concerned with the internal accumulation of resources and their specificity. Unsurprisingly, the acquisition of unique and valuable resources implies high transaction costs. Thus, competitive advantage flows from the ability to restrict access to a resource or the exploitation of same. By applying such restrictions, firms can sustain long-term benefits and outdistance competitors. RBV makes it possible to identify strategic resources (competences and strategies) and evaluate their association with superior performance.

According to Perez and Famá (2006) and Teh, Kayo and Kimura (2008), market integration has intensified competition globally, requiring firms to strive harder for differentiation. To build competitive advantage, firms are increasingly investing in intangible resources (brands, patents and intellectual capital) since innovation allows for greater control over specific resources and potentially aggregates value, boosting performance. 
Tidd, Bessant and Pavitt (2008) stress that, regardless of commercial, social and technological conditions, organizations must continually innovate to sustain competitive advantage. As we have seen, RBV assumes that resources and competences (including strategies), if employed adequately, can boost corporate performance and create differentiation. Since the purpose of innovation is to diversify products and markets in order to raise competitive barriers, a proper understanding of RBV brings into clearer focus the association between innovation and performance (Barney, 1996; Priem, \& Butler, 2001).

Moreover, it has been argued that innovation in firms is influenced by the external institutional environment (Alam, Uddin, \& Yazdifar, 2019; Rajapathirana, \& Hui, 2018): economic, social, political, legal, regulatory, technological and market competition factors may all encourage or discourage corporate investment in innovation. According to Alam, Uddin and Yazdifar (2019), this perspective of the innovation problematic is particularly pertinent to emerging economies like Brazil.

Alam, Uddin and Yazdifar (2019) analyzed information on 664 firms from 20 emerging economies (including Brazil, China, India, Russia, South Africa and Turkey), covering the period 2006-2013. Their results support the notion that institutional factors have a significant influence on investment in innovation. Thus, government efficiency, regulation and legal structure were found to stimulate innovative efforts, while the opposite was true for political instability and corruption. This reiterates the value of analyses of the innovative profile of firms operating in different economic contexts, such as the current study.

However, rather than clarifying the issue, empirical analyses have raised many new questions about the association between innovation and performance. For example, while Baaij, Greeven and Van Dalen (2004) found that a considerable proportion of IT firms displayed sustained superior returns attributable to innovation, in an analysis of the relation between innovation (brands and patents) and market value, Teh, Kayo and Kimura (2008) concluded that only brands contributed to the creation of competitive advantage and company appreciation. In Brito, Brito and Morganti (2009), innovation was positively correlated with revenues, but not with profitability, suggesting innovation favors business sales. Silveira and Oliveira (2013) reached conclusions similar to those of Brito, Brito and Morganti (2009), whereas Carvalho, Kayo and Martin (2010), Jensen, Menezes-Filho and Sbragia (2004) and Santos et al. (2014) observed no correlation between innovation and performance parameters. Finally, to Jefferson et al. (2003), innovation deteriorates performance.

In light of RBV, these discrepancies may be explained by the concept of heterogeneity. As shown by Barney (1991) and Hart (1995), the strength of the connection between resources and competitive advantage depends on the firm's competences. In a wider sense, innovation may involve multiple perspectives (e.g., acquisition of patents or large investments in R\&D) depending on the strategies adopted. In part, this accounts for the observed differences in the impact of innovation on performance. In fact, according to Pippel (2015), the contribution of R\&D to corporate performance is not necessarily beneficial. More research is needed to explore and clarify these relationships.

In this regard, Salimi and Rezaei (2018) concur with Rajapathirana and Hui (2018) who concluded that innovation has a range of different effects on corporate performance considered within a broad scope of perspectives (e.g., financial, innovation and learning, consumers, and businessspecific internal activities and routines).

In a study by Rajapathirana and Hui (2018) involving 379 corporate managers, the participants were asked to describe the relationship between innovative capacity, types of innovation and corporate performance. Focused on the emerging market of Sri Lanka, the study revealed that the greater the innovative capacity and efforts, the better the economic and financial performance.

Innovation, considered a strategic resource, may be classified into two types: exploratory and exploitative (March, 1991). The former is associated with characteristics such as flexibility, discovery, experimentation and exposure to risk, while the latter is expressed in refining, production, selection, efficiency and execution. The former is a radical breakaway from existing products and practices, the latter is continual, incremental improvement (March, 1991). 
Kim (2015) believes that investment in exploratory (or "pure") innovation, such as R\&D, increases a firm's innovative potential. Exploratory innovation is associated with greater risks, and return on investment is less predictable. Nevertheless, Gilsing and Nooteboom (2006) believe that a well-managed combination of the two types of innovation within the organizational structure increases chances of corporate survival on the market. While exploitative (incremental) innovation meets short-term market demands, exploratory innovation strengthens competitive advantage in the long run. Thus, by carefully balancing investments in innovation, firms can consolidate their competitive advantage, aggregate value and boost long-term performance (Gomes et al., 2013).

Almahendra and Ambos (2015) highlight that, due to limited corporate resources, the choice of type of innovation (exploratory vs. exploitative) for the organizational structure involves tradeoffs which are often determined by the expected impact of innovation on performance. This is supported by Scandelari and Cunha (2013), according to whom the creation of competitive advantage is essentially a question of ambidexterity, i.e., the ability to balance investments in exploratory and exploitative innovation. To sustain competitive advantage, firms should avoid focusing on only one type of innovation and invest their efforts in a balanced set of alternatives (Gomes, Kruglianskas, \& Scherer, 2012).

The possible association between innovation and performance has been explored by several scholars (Jiang, \& Stark, 2013; Gong, \& Wang, 2016; Songur, \& Heavilin, 2017; Gonçalves, \& Lemes, 2019) by examining the informational relevance of the disclosure of expenditure on innovation (especially $R \& D$ ).

Generally speaking, the above studies show that this type of disclosure is relevant to investors and has a positive impact on market value. According to Jiang and Stark (2013), expenditure on innovation signalled positive future perspectives for 4,852 observations of UK firms between 1991 and 2010.

Likewise, Songur and Heavilin (2017) found abnormal increases in R\&D spending to be associated with greater returns on stocks in innovative firms, confirming the expectation that exploratory innovation greatly favors corporate performance (March, 1991; Kim, 2015), at least from the market perspective. The sample used by Songur and Heavilin (2017) consisted of firms traded on NYSE, AMEX and NASDAQ between 1975 and 2015.

In a study on firms from innovation and technology-intensive sectors, Gonçalves and Lemes (2019) reached conclusions similar to those of Jiang and Stark (2013) and Songur and Heavilin (2017). Thus, in their analysis of the Brazilian setting, the authors found the ratio between R\&D spending and total assets to be predictive of future economic benefits.

On the other hand, as shown by Gong and Wang (2016), in countries with weak legal and economic investor protection, disclosure of $R \& D$ spending becomes less relevant. This is because fragile institutional environments foster uncertainty regarding future contracts and therefore have negative impacts on expectations for future economic benefits.

Exploitative innovation makes use of existing resources, while exploratory innovation may be defined as a prospection for new resources (Scandelari, \& Cunha, 2013). Ambidexterity is made possible by awareness of the ideal mix of resources and ability to reconcile essentially conflicting demands. The focus of some strategies on alignment (exploitation) and others on adaptability (exploration) reflects the heterogeneous nature of innovation, as suggested by RBV. In this study, we considered the concept of ambidexterity from multiple perspectives (inputs, intangible assets of innovation, outputs and disclosure) in order to evaluate the effects of innovation on performance (expressed as ROA and ROE) in sustainable Brazilian and European firms.

Ambidexterity is not merely a question of combining contrasting forms of innovation to create competitive advantage and boost performance; it also reflects corporate commitment to innovation and sustainability (Scandelari, \& Cunha, 2013). The logic employed in the interpretation of complementarity is useful in the analysis of innovation strategies; i.e., by adopting complementary strategies, firms become more responsive to market competition. Thus, firms committed to 
ambidexterity in the wider sense described above (giving adequate attention to both short-term and long-term perspectives) are likely to increase their market share (Gilsing, \& Nooteboom, 2006).

Adopting the strategic ambidexterity approach (Scandelari, \& Cunha, 2013), Silvestre and Țîrcă (2019) created a model to explore the respective emphasis of different innovation types flowing from sustainability demands. While conventional innovation gives priority to economic gain and therefore tends to have a small impact on sustainability, social and green innovation is often directed at long-term, non-economic objectives. In the opinion of Silvestre and Țîrcă (2019), firms should ideally invest in innovation of the sustainable type, provided a balance exists as described by Gilsing and Nooteboom (2006).

Based on this discussion, we investigated the relationship between innovation and performance in sustainable firms. Viewing sustainability as an important factor in the creation of competitive advantage (HART, 1995), several authors have reported a positive correlation between sustainability and performance (Pätäri et al., 2014; Saeidi et al., 2015). Others have found no such relation (Hackston, \& Milne, 1996; Machado, \& Machado, 2011). Leaving aside the question of inconsistent results (which is not the object of the present study), the evaluation may be framed in a different perspective, based on RBV.

It has been argued that innovation is strongly influenced by the internal and external corporate environment (e.g., Barbieri et al., 2010; Bessant, \& Tidd, 2009; Gomes et al., 2009; Hall, \& Vredenburg, 2003; Kim, 2015). Indeed, market demands and pressure from stakeholders for the adoption of sustainable practices may lead firms to change their innovation priorities, or at least make parallel investments in sustainable practices (Barbieri et al., 2010; Bessant, \& Tidd, 2009; Carvalho, \& Barbieri, 2013; González-Benito, \& González-Benito, 2006). This supports the RBV concept of dynamic capabilities as a set of specific conditions and competences capable of boosting competitive advantage (Barney, 1991). Thus, while pursuing innovation for the sake of competitive advantage and economic gain, firms may at the same time be legitimized through their commitment to sustainability.

The present study differs from previous investigations of the association between innovation and performance by applying the problematic to a sample of Brazilian and European firms classified as sustainable in their respective markets. It is hoped our findings will help identify the corporate strategies required to build competitive advantage and meet the demands of the market for sustainable practices. The methodology employed to do so is described in the following section.

\section{METHODS}

\subsection{Sampling}

Descriptive and quantitative, the study was designed as a comprehensive analysis of secondary data. The sample was drawn from a universe of Brazilian and European industrial firms meeting one or more of the following criteria of sustainability (as of 24 March 2015): i) Index of Corporate Sustainability (ISE), ii) Index of Carbon Efficiency (ICO2), and iii) Low Carbon 100 Europe Index ${ }^{\circledR}$. The first two indices are sponsored by B3; the third is sponsored by NYSE Euronext. The criteria allowed to compose a sample of 57 Brazilian and 100 European firms. According to Beato, Souza and Parisotto (2009), these indices help potential investors identify profitable firms adhering to sustainable practices.

The Oslo Manual $(2005,2018)$ was used to collect and interpret data on innovation. According to the manual (2005, p. 46), "an innovation can be more narrowly categorized as the implementation of one or more types of innovations, for instance product and process innovations". Thus, evaluations of innovative profiles should take into account different approaches and variables, including expenditure on innovation, results from innovation activity, human capital, impact of innovation on activities, incentives, actions and practices, demand, laws and regulations, linkages and the role of diffusion (Oslo Manual, 2005, 2018). 
Based on the tenets of the Oslo Manual (2005, 2018), Table 1 specifies which innovationrelated items were measured in this paper.

Table 1 - Innovation items measured

\begin{tabular}{|c|c|}
\hline Area of investigation according to the Oslo Manual (2005, 2018) & Evaluated item \\
\hline Expenditure on innovation & Investments in R\&D \\
\hline Results from innovation activity and human capital & Intangible innovation assets and patents \\
\hline Action and practices & $\begin{array}{c}\text { Disclosure of qualitative information on } \\
\text { innovation }\end{array}$ \\
\hline Impact of innovation on activities & Impact on corporate performance \\
\hline
\end{tabular}

Source: Oslo Manual (2005, 2018).

Firms with available data on innovation and performance covering the period 2010-2013 were eligible, with a single exception (data for Ambev S.A. Brazil was limited to 2012-2013), yielding a final sample of 78 firms (26 Brazilian and 52 European) (Table 2).

Table 2 - Firms included in the final sample according to country/region

\begin{tabular}{lcclcc}
\hline Country/Region & $\mathbf{n}$ & \% & Country/Region & $\mathbf{n}$ & \% \\
\hline Brazil & 26 & 33 & Finland & 2 & 3 \\
U.K. & 11 & 14 & Netherlands & 2 & 3 \\
France & 10 & 13 & Italy & 2 & 3 \\
Switzerland & 7 & 9 & Belgium & 1 & 1 \\
Germany & 6 & 8 & Denmark & 1 & 1 \\
Spain & 4 & 5 & Ireland & 1 & 1 \\
Sweden & 4 & 5 & Norway & 1 & 1 \\
\hline
\end{tabular}

Source: ISE (2014), ICO2 (2015) and Low Carbon 100 Europe $^{\circledR}$ (2014), covering the period of data collection. The information was retrieved from the websites of B3 (2015) and Euronext (2015).

Based on a total of 310 observations, Brazil had the largest participation in the sample (33\%), followed by the U.K. and France. After defining the sample, the study variables were defined and collected.

\subsection{Variables}

The study was based on the assumption that innovation is positively associated with performance, as postulated by RBV. To evaluate the association, innovation was quantified using multiple variables. The first metric was investments in R\&D-an expression of corporate efforts at high-risk innovation (March, 1991). This metric was also used by Brito et al. (2009), Chauvin and Hirschey (1993), Jensen et al. (2004), Lee and Chen (2009), Nekhili, Boubaker and Lakhal (2012), Santos et al. (2014), and Silva and Suzigan (2014). Information on investments in R\&D was retrieved from financial and performance reports published by each firm during the study period.

The second metric was intangible innovation assets (brands, know-how, intellectual property, etc.), represented by consolidated (low-risk) innovation recognized in financial reports (March, 1991). The metric was previously used by Chen (2009), Hsu (2007), Lev (2001), Marqués, Simón and Carañana (2006), Rogers (1998) and Santos et al. (2014). Information on intangible innovation assets was retrieved from financial reports.

The third metric was patents registered by the firm, i.e., low-risk established innovation restricted to the firm (March, 1991) - an output of innovative effort. This metric is widely used in studies on innovation (Megna, \& Klock, 1993; Deng, Lev, \& Narin, 1999; Kayo, The, \& Basso, 2006; Moura, \& Galina, 2009; Teh et al., 2008; Póvoa, 2010). Information on patents was retrieved from the Espacenet database (2015) which is networked with patent offices around the world, including the Brazilian Institute of Intellectual Property (INPI) and the European Patent Office (EPO).

The fourth metric was based on the disclosure of qualitative information on innovation. The use of this metric is supported by Ding, Entwistle and Stolowy (2004), Floriani, Beuren and Hein (2010), Gu and Li (2003), Nekhili, Boubaker and Lakhal (2012), and Vicenti, Gomes and Machado (2013). In the present study, we adopted the method proposed by Gu and Li (2003). Information was 
collected from annual and management reports describing innovation strategies and advances, development and purchase of new technology. Data were collected based on content analysis. The information was organized with a check list containing 19 items, with one point assigned for each item checked (Table 3). The result was expressed as a percentage.

Table 3 - Items of disclosure of innovation activities in Annual and Management Reports

\begin{tabular}{|l|}
\hline \multicolumn{1}{|c|}{ Information about corporate innovation by category/item } \\
\hline 1. Articulation, explanation and discussion of strategy \\
\hline 2. Nature of innovation (e.g., basic research, process and product development) \\
\hline 3. Goal, objective or plan of innovation \\
\hline 4. Relation with current innovation (e.g., strategic new initiative, enhancement of existing technology) \\
\hline 5. Time frame (e.g., years to complete) \\
\hline 6. Amount of financing or spending planned \\
\hline 7. Form of R\&D venture (e.g., alliance with other firms, contracting with government or other firms) \\
\hline 8. Acquisition of other firms for new technology or other innovation capabilities \\
\hline 9. Breakthrough or milestone in R\&D projects \\
\hline 10. Details of pipeline projects or new products under development \\
\hline 11. Human capital (e.g., turnover of star scientists and details on research teams) \\
\hline 12. Implementation, continuation or termination of R\&D projects \\
\hline 13. Continuation of available financing \\
\hline 14. Indication of whether R\&D programs are on schedule \\
\hline 15. New product launch or acceptance by the market \\
\hline 16. Patent licensing and royalty \\
\hline 17. Transfer or sale of technology or patent \\
\hline 18. Marketing alliance for new products \\
\hline 19. Litigation concerning intellectual properties (e.g., patent infringement and breach of licensing agreements) \\
\hline Source: Gu and Li (2003). \\
\hline
\end{tabular}

Corporate performance was quantified with the variables ROA (return on assets, i.e. net earnings divided by total assets) and ROE (return on equity, i.e. net earnings divided by equity). The same indicators were used by Brito, Brito and Morganti (2009), Floriani, Beuren and Hein (2013) and Santos et al. (2014). The use of multiple performance indicators is recommended by Matitz and Bulgacov (2011) due to differences in interpretation flowing from each perspective.

\subsection{Quantitative approach}

The findings of our analysis of the association between innovation profile and performance were analyzed with the Mann-Whitney test and the Kruskal-Wallis test. Correlations between average performance and innovation variables were tested considering i) the presence/absence of each type of innovation, ii) disclosure of information on innovation according to the check list of $\mathrm{Gu}$ and $\mathrm{Li}$ (2003), and iii) level of diversification of innovation.

As we have seen, competitive advantage may take the form of position barriers preventing rivals from accessing and exploiting specific resources. According to RBV, this advantage may translate into enhanced performance (Barney, 1991; Gomes et al., 2013; Peteraf, 1993; Wernerfelt, 1984). Performance would therefore be expected to be superior in innovative firms, especially those which disclose information on innovation strategies to help potential investors make decisions (GU; LI, 2003). It should be kept in mind that different types of innovation are associated with different levels of risk and, consequently, different levels of gains. Firms are advised to employ a mix of innovation types to remain competitive in the short and long run, in addition to disclosing information on their innovation strategies and activities (Gilsing, \& Nooteboom, 2006; Gu, \& Li, 2003; Kim, 2015; March, 2001; Scandelari, \& Cunha, 2013). It is therefore reasonable to assume that firms with different levels of diversification of innovation differ with regard to performance. All quantitative analyses were performed with the software SPSS. 


\section{RESULTS}

The collected information allowed us to draw innovation profiles for the 78 Brazilian and European firms in the sample. Initially, we focused on innovation as a strategic resource (Table 4).

Table 4 - Innovation profile of 26 Brazilian and 52 European firms

\begin{tabular}{|c|c|c|c|c|c|c|c|c|}
\hline \multirow[b]{2}{*}{2010} & \multicolumn{2}{|c|}{ R\&D } & \multicolumn{2}{|c|}{$\begin{array}{c}\text { Intangible innovation } \\
\text { assets }\end{array}$} & \multicolumn{2}{|c|}{ Patents } & \multicolumn{2}{|c|}{ Disclosure } \\
\hline & Yes & No & Yes & No & Yes & No & Yes & No \\
\hline Brazil & $7(28 \%)$ & 18 & $18(72 \%)$ & 7 & $7(28 \%)$ & 18 & $16(64 \%)$ & 9 \\
\hline Europe & $42(81 \%)$ & 10 & $39(75 \%)$ & 13 & $35(67 \%)$ & 17 & $45(87 \%)$ & 7 \\
\hline 2011 & Yes & No & Yes & No & Yes & No & Yes & No \\
\hline Brazil & $6(24 \%)$ & 19 & $20(80 \%)$ & 5 & $7(28 \%)$ & 18 & $18(72 \%)$ & 7 \\
\hline Europe & $42(81 \%)$ & 10 & $39(75 \%)$ & 13 & $32(62 \%)$ & 20 & $46(88 \%)$ & 6 \\
\hline 2012 & Yes & No & Yes & No & Yes & No & Yes & No \\
\hline Brazil & $6(23 \%)$ & 20 & $20(77 \%)$ & 6 & $12(46 \%)$ & 14 & $17(65 \%)$ & 9 \\
\hline Europe & $41(79 \%)$ & 11 & $39(75 \%)$ & 13 & $32(62 \%)$ & 20 & $47(90 \%)$ & 5 \\
\hline 2013 & Yes & No & Yes & No & Yes & No & Yes & No \\
\hline Brazil & $6(23 \%)$ & 20 & $18(69 \%)$ & 8 & $11(42 \%)$ & 15 & $18(69 \%)$ & 8 \\
\hline Europe & $40(77 \%)$ & 12 & $38(73 \%)$ & 14 & $34(65 \%)$ & 18 & $48(92 \%)$ & 4 \\
\hline
\end{tabular}

Source: research data, 2016.

The notion of innovation as essential and indispensable (Gomes et al., 2013; Santos et al., 2014; The, Kayo, \& Kimura, 2008; Tidd, Bessant, \& Pavitt, 2008) is called into question by the existence of significant heterogeneity within firms (Barney, 1991), innovation types (Almahendra, Ambos, 2015; Gilsing, \& Nooteboom, 2006; Gomes, Kruglianskas, \& Scherer, 2012; Scandelari, \& Cunha, 2013) and economic environments (Lundvall et al., 2002; Tidd, Bessant, \& Pavitt, 2008; Vermulm, \& Hollanda, 2006).

This is reflected in the data shown in Table 4. For example, while a priority in European firms, exploratory innovation (R\&D) is given little attention by Brazilian firms. In contrast, the two groups are comparable with regard to the incorporation of intangible innovation assets (brands, internally developed assets, patents, know-how, intellectual property and copyrights), indicating the economic relevance of such assets (Carvalho, Kayo, \& Martin, 2010; Lev, 2001; Marqués, Simón, \& Carañana, 2006).

The discrepancy with regard to the number of firms with patents in each group may be explained a priori by differences in R\&D investment patterns (Table 5), but may also be the result of region-specific institutional structures and innovation strategies (Arruda, Vermulm, \& Hollanda, 2006; Lundvall et al., 2002; Tidd, Bessant, \& Pavitt, 2008). Nevertheless, despite assigning less importance to patents in general, Brazilian firms displayed greater proportional growth in innovation efforts (inputs vs. outputs).

Table 5 - Descriptive analysis of average investments in innovation by 78 sustainable Brazilian and European firms

\begin{tabular}{|c|c|c|c|c|c|}
\hline & \multirow[t]{2}{*}{ Region } & R\&D & $\begin{array}{c}\text { Intangible } \\
\text { innovation assets }\end{array}$ & Patents & \multirow[t]{2}{*}{ Disclosure } \\
\hline & & \multicolumn{3}{|c|}{ Mean values in thousand BRL } & \\
\hline \multirow{2}{*}{2010} & Brazil & 73,299 & 210,147 & 5 & $19 \%$ \\
\hline & Europe & $2,366,146$ & $2,560,512$ & 20 & $22 \%$ \\
\hline \multirow{2}{*}{2011} & Brazil & 87,578 & 298,911 & 9 & $19 \%$ \\
\hline & Europe & $2,755,090$ & $3,542,457$ & 34 & $22 \%$ \\
\hline \multirow{2}{*}{2012} & Brazil & 95,844 & 462,705 & 7 & $20 \%$ \\
\hline & Europe & $3,183,700$ & $3,663,522$ & 61 & $22 \%$ \\
\hline \multirow{2}{*}{2013} & Brazil & 97,243 & 601,341 & 9 & $19 \%$ \\
\hline & Europe & $3,868,798$ & $4,189,151$ & 73 & $22 \%$ \\
\hline
\end{tabular}

Source: research data, 2016. 
The disclosure of information on innovation may be relevant or even crucial to the performance and market value of firms (Gomes, Kruglianskas, \& Scherer, 2012; Gu, \& Li, 2003) as it reflects efforts at managing strategic resources. Though practiced to some degree by most firms, disclosure was predominant in the European subsample. Table 5 provides further details.

On the average, sustainable European firms invested more efforts in innovation (inputs, intangible innovation assets and outputs), and made more disclosure of it, than sustainable Brazilian firms. When analyzing the results, the economic and institutional differences between Brazil (a developing economy) and Europe (a group of developed economies) (Lundvall et al., 2002; Tidd, Bessant, \& Pavitt, 2008) should be taken into account. According to Arruda, Vermulm and Hollanda (2006), the development of technologies and strategies of know-how accumulation remains slower in Brazil than in most developed countries. In state-controlled organizations, innovation is apparently not seen as an important source of competitiveness.

As demonstrated by Silva and Suzigan (2014), the reality of the market strongly influences corporate practices and efforts at innovation in the quest for competitive advantage. Other factors may explain the observed differences, such as company size, sector and the life cycle of technologies and industries (Silva, \& Suzigan, 2014; Tidd, Bessant, \& Pavitt, 2008).

Moreover, according to $\mathrm{Gu}$ and $\mathrm{Li}$ (2003), disclosure has increased in response to demands from investors because it is perceived as relevant to decision making and company appreciation. As pointed out by Vicenti, Gomes and Machado (2013), disclosure allows stakeholders to monitor the implementation of innovations and strategies and their impact, if any, on market value and performance.

Following our analysis of the three perspectives on innovation and the disclosure of related information by sustainable Brazilian and European firms, we analyzed the correlation between innovation and performance. Starting with the Brazilian subsample, our results are presented in Tables 6, 7, 8 and 9.

Table 6 - Mann-Whitney analysis of innovation vs. mean performance in 26 sustainable Brazilian firms

\begin{tabular}{|c|c|c|c|c|c|c|c|c|c|}
\hline \multirow{2}{*}{\multicolumn{2}{|c|}{$\begin{array}{c}\text { Innovation } x \text { performance } \\
\text { R\&D } \\
\end{array}$}} & \multicolumn{2}{|c|}{2010} & \multicolumn{2}{|c|}{2011} & \multicolumn{2}{|c|}{2012} & \multicolumn{2}{|c|}{2013} \\
\hline & & mean & $p$-value & mean & $p$-value & mean & $p$-value & mean & $p$-value \\
\hline $\begin{array}{l}\text { Yes } \\
\text { No }\end{array}$ & ROA & $\begin{array}{r}9.0 \% \\
8.2 \%\end{array}$ & 0.762 & $\begin{array}{r}8.0 \% \\
6.0 \%\end{array}$ & 0.703 & $\begin{array}{l}5.2 \% \\
6.3 \%\end{array}$ & 0.761 & $\begin{array}{l}4.8 \% \\
5.6 \%\end{array}$ & 0.903 \\
\hline $\begin{array}{l}\text { Yes } \\
\text { No }\end{array}$ & ROE & $\begin{array}{r}\mathbf{2 1 . 5 \%} \\
19.1 \% \\
\end{array}$ & 0.545 & $\begin{array}{l}19.2 \% \\
19.2 \% \\
\end{array}$ & 0.703 & $\begin{array}{r}\mathbf{1 6 . 4 \%} \\
16.3 \% \\
\end{array}$ & 0.761 & $\begin{array}{l}\mathbf{1 9 . 0 \%} \\
15.2 \% \\
\end{array}$ & 0.808 \\
\hline Intangibles & & mean & $p$-value & mean & $p$-value & mean & $p$-value & mean & $p$-value \\
\hline $\begin{array}{l}\text { Yes } \\
\text { No }\end{array}$ & ROA & $\begin{array}{r}8.6 \% \\
8.0 \%\end{array}$ & 0.809 & $\begin{array}{l}6.5 \% \\
6.6 \%\end{array}$ & 0.587 & $\begin{array}{r}6.0 \% \\
5.9 \%\end{array}$ & 0.503 & $\begin{array}{l}\mathbf{5 . 6 \%} \\
5.0 \%\end{array}$ & 0.956 \\
\hline $\begin{array}{l}\text { Yes } \\
\text { No }\end{array}$ & ROE & $\begin{array}{r}\mathbf{2 0 . 5 \%} \\
17.8 \% \\
\end{array}$ & 1.000 & $\begin{array}{l}\mathbf{1 5 . 4 \%} \\
15.3 \% \\
\end{array}$ & 0.587 & $\begin{array}{r}\mathbf{1 6 . 5 \%} \\
15.7 \% \\
\end{array}$ & 0.429 & $\begin{array}{l}15.3 \% \\
\mathbf{1 7 . 8 \%} \\
\end{array}$ & 0.697 \\
\hline Patents & & mean & $p$-value & mean & $p$-value & mean & $p$-value & mean & $p$-value \\
\hline $\begin{array}{l}\text { Yes } \\
\text { No }\end{array}$ & ROA & $\begin{array}{l}6.6 \% \\
9.2 \% \\
\end{array}$ & 0.762 & $\begin{array}{r}7.7 \% \\
6.1 \% \\
\end{array}$ & 0.586 & $\begin{array}{l}6.0 \% \\
6.1 \% \\
\end{array}$ & 0.719 & $\begin{array}{l}7.1 \% \\
4.2 \% \\
\end{array}$ & 0.586 \\
\hline $\begin{array}{l}\text { Yes } \\
\text { No }\end{array}$ & ROE & $\begin{array}{r}14.4 \% \\
\mathbf{2 2 . 1 \%} \\
\end{array}$ & 0.672 & $\begin{array}{l}17.7 \% \\
14.5 \% \\
\end{array}$ & 0.717 & $\begin{array}{l}15.7 \% \\
\mathbf{1 6 . 9 \%} \\
\end{array}$ & 0.280 & $\begin{array}{r}20.1 \% \\
13.1 \% \\
\end{array}$ & 0.622 \\
\hline Disclosure & & mean & $p$-value & mean & $p$-value & mean & $p$-value & mean & $p$-value \\
\hline $\begin{array}{l}\text { Yes } \\
\text { No }\end{array}$ & ROA & $\begin{array}{l}9.2 \% \\
7.2 \%\end{array}$ & 0.651 & $\begin{array}{r}6.7 \% \\
6.2 \%\end{array}$ & 0.431 & $\begin{array}{l}5.4 \% \\
7.3 \%\end{array}$ & 0.346 & $\begin{array}{l}4.9 \% \\
6.5 \%\end{array}$ & 0.470 \\
\hline $\begin{array}{l}\text { Yes } \\
\text { No }\end{array}$ & ROE & $\begin{array}{r}\mathbf{2 0 . 2 \%} \\
19.2 \% \\
\end{array}$ & 0.365 & $\begin{array}{r}14.6 \% \\
\mathbf{1 7 . 4 \%} \\
\end{array}$ & 0.250 & $\begin{array}{l}14.4 \% \\
\mathbf{2 0 . 0 \%} \\
\end{array}$ & 0.225 & $\begin{array}{l}14.3 \% \\
\mathbf{2 0 . 0} \% \\
\end{array}$ & 0.317 \\
\hline
\end{tabular}

Note: ROA=return on assets; ROE=return on equity.

Source: research data, 2016.

According to RBV, if exploited as a strategic resource, innovation can lead to competitive advantage. The latter may be in the form of superior performance compared to that of non-innovative firms, but the concept of economic superiority implies persistence (Baaij, Greeven, \& Van Dalen, 2004; Carvalho, Kayo, \& Martin, 2010). Table 5 shows evidence of improved performance in 
Brazilian firms investing in $R \& D$ and intangibles but, when submitted to the Mann-Whitney test, these differences were neither significant nor persistent throughout the study period.

Firms making no disclosure of information on innovation, as quantified with the index of $\mathrm{Gu}$ and Li (2003), displayed the best performance, contradicting the findings of Gomes, Kruglianskas and Scherer (2012), Gu and Li (2003) and Vicenti, Gomes and Machado (2013). However, it should be kept in mind that this type of disclosure is not only voluntary but involves certain costs, especially in the case of specific strategic information, and that the advantage of expressing commitment to sustainable practices may have led some firms to deprioritize disclosure on innovation. As pointed out by Barbieri et al. (2010), although innovation and sustainability can both aggregate competitive advantage, at some levels they are mutually exclusive.

As shown in the following (Table 7), results were different for the European subsample.

Table 7 - Mann-Whitney analysis of innovation vs. mean performance in 52 sustainable European firms

\begin{tabular}{|c|c|c|c|c|c|c|c|c|c|}
\hline \multirow{2}{*}{\multicolumn{2}{|c|}{$\begin{array}{c}\text { Innovation } x \text { performance } \\
\text { R\&D } \\
\end{array}$}} & \multicolumn{2}{|c|}{2010} & \multicolumn{2}{|c|}{2011} & \multicolumn{2}{|c|}{2012} & \multicolumn{2}{|c|}{2013} \\
\hline & & mean & $p$-value & mean & $p$-value & mean & $p$-value & mean & $p$-value \\
\hline $\begin{array}{l}\text { Yes } \\
\text { No }\end{array}$ & ROA & $\begin{array}{l}6.1 \% \\
7.0 \%\end{array}$ & 1.000 & $\begin{array}{l}6.0 \% \\
7.4 \%\end{array}$ & 0.531 & $\begin{array}{l}\mathbf{5 . 7 \%} \\
5.6 \%\end{array}$ & 0.538 & $\begin{array}{l}5.2 \% \\
6.1 \%\end{array}$ & 0.617 \\
\hline $\begin{array}{l}\text { Yes } \\
\text { No }\end{array}$ & ROE & $\begin{array}{l}18.5 \% \\
\text { 33.0\% }\end{array}$ & 0.457 & $\begin{array}{l}18.6 \% \\
\mathbf{2 4 . 5 \%}\end{array}$ & 0.416 & $\begin{array}{l}15.9 \% \\
\mathbf{2 5 . 9 \%}\end{array}$ & 0.509 & $\begin{array}{r}13.7 \% \\
\mathbf{2 3 . 9 \%} \\
\end{array}$ & 0.278 \\
\hline Intangibles & & mean & $p$-value & mean & $p$-value & mean & $p$-value & mean & $p$-value \\
\hline $\begin{array}{l}\text { Yes } \\
\text { No }\end{array}$ & ROA & $\begin{array}{l}6.2 \% \\
6.5 \%\end{array}$ & 0.492 & $\begin{array}{l}6.4 \% \\
6.1 \%\end{array}$ & 0.466 & $\begin{array}{r}6.2 \% \\
4.2 \%\end{array}$ & 0.547 & $\begin{array}{l}\mathbf{5 . 9 \%} \\
4.1 \%\end{array}$ & 0.173 \\
\hline $\begin{array}{l}\text { Yes } \\
\text { No }\end{array}$ & $\mathrm{ROE}$ & $\begin{array}{l}\mathbf{2 1 . 6 \%} \\
20.4 \%\end{array}$ & 0.404 & $\begin{array}{l}19.9 \% \\
\mathbf{2 0 . 0 \%}\end{array}$ & 0.547 & $\begin{array}{l}19.3 \% \\
14.0 \%\end{array}$ & 0.743 & $\begin{array}{r}\mathbf{1 8 . 3 \%} \\
10.2 \%\end{array}$ & 0.117 \\
\hline Patents & & mean & $p$-value & mean & $p$-value & mean & $p$-value & mean & $p$-value \\
\hline $\begin{array}{l}\text { Yes } \\
\text { No }\end{array}$ & ROA & $\begin{array}{l}6.2 \% \\
6.4 \%\end{array}$ & 0.592 & $\begin{array}{r}6.3 \% \\
6.2 \%\end{array}$ & 0.638 & $\begin{array}{r}6.3 \% \\
4.8 \%\end{array}$ & 0.560 & $\begin{array}{l}\mathbf{5 . 6 \%} \\
5.0 \%\end{array}$ & 0.832 \\
\hline $\begin{array}{l}\text { Possui } \\
\text { No }\end{array}$ & ROE & $\begin{array}{r}\mathbf{2 2 . 9 \%} \\
18.0 \% \\
\end{array}$ & 0.578 & $\begin{array}{r}\mathbf{2 1 . 1 \%} \\
18.2 \% \\
\end{array}$ & 0.573 & $\begin{array}{r}\mathbf{2 1 . 1 \%} \\
13.0 \% \\
\end{array}$ & 0.357 & $\begin{array}{l}\mathbf{1 6 . 6 \%} \\
15.2 \%\end{array}$ & 1.000 \\
\hline Disclosure & & mean & $p$-value & mean & $p$-value & mean & $p$-value & mean & $p$-value \\
\hline $\begin{array}{l}\text { Yes } \\
\text { No }\end{array}$ & ROA & $\begin{array}{l}6.0 \% \\
\mathbf{8 . 1 \%}\end{array}$ & 0.414 & $\begin{array}{l}5.9 \% \\
9.7 \%\end{array}$ & $0.032 * *$ & $\begin{array}{l}5.4 \% \\
\mathbf{8 . 2 \%}\end{array}$ & 0.257 & $\begin{array}{l}5.2 \% \\
\mathbf{7 . 6 \%}\end{array}$ & 0.606 \\
\hline $\begin{array}{l}\text { Divulgou } \\
\text { No }\end{array}$ & ROE & $\begin{array}{l}18.6 \% \\
\mathbf{3 8 . 7 \%}\end{array}$ & 0.511 & $\begin{array}{l}18.2 \% \\
\mathbf{3 3 . 0 \%}\end{array}$ & 0.115 & $\begin{array}{l}16.4 \% \\
\mathbf{3 2 . 7 \%}\end{array}$ & 0.284 & $\begin{array}{l}14.6 \% \\
\mathbf{3 3 . 5 \%}\end{array}$ & 0.680 \\
\hline
\end{tabular}

Note: $* *=$ significant at the level of $5 \% ; \mathrm{ROA}=$ return on assets; ROE=return on equity.

Source: research data, 2016.

In our sample of European firms, exploratory innovation (R\&D) was not associated with superior but with inferior performance (Table 7). Conversely, investments in patents (outputs) showed evidence of improved performance in almost the entire study period, although the difference was not statistically significant. In a study by Teh, Kayo and Kimura (2008), patents were not associated with aggregated value in Brazilian firms, but brands (intangibles) were. In view of the claim of Arruda, Vermulm and Hollanda (2006) and Silva and Suzigan (2014) that country-specific conditions affect innovation patterns (Lundvall et al., 2002; Tidd, Bessant, \& Pavitt, 2008) and the fact that innovation employed as a strategic resource potentially affects economic performance, it is reasonable to assume that breakthrough innovation has less influence on corporate performance in developed economies than in emerging economies.

The opposite may be observed for consolidated innovation (patents). In a country which like Brazil lags behind in terms of investment in innovation (Arruda, Vermulm, \& Hollanda, 2006), firms can fairly easily acquire a competitive advantage by innovating and disclosing their efforts to do so. The overall high level of disclosure on innovation in European countries would render that strategy less attractive, making it more profitable to invest in consolidated innovation, such as patents.

The relation between innovation and performance was also analyzed for the full sample, as shown below (Table 8). 
Table 8 - Mann-Whitney analysis of innovation vs. mean performance in sustainable Brazilian and European firms (full sample)

\begin{tabular}{|c|c|c|c|c|c|c|c|c|c|}
\hline \multirow{2}{*}{\multicolumn{2}{|c|}{$\begin{array}{l}\text { Innovation } x \text { performance } \\
\text { R\&D }\end{array}$}} & \multicolumn{2}{|c|}{2010} & \multicolumn{2}{|c|}{2011} & \multicolumn{2}{|c|}{2012} & \multicolumn{2}{|c|}{2013} \\
\hline & & mean & $p$-value & mean & $p$-value & mean & $p$-value & mean & $p$-value \\
\hline $\begin{array}{l}\text { Yes } \\
\text { No }\end{array}$ & ROA & $\begin{array}{l}6.5 \% \\
\mathbf{7 . 6 \%}\end{array}$ & 0.735 & $\begin{array}{l}6.3 \% \\
6.5 \%\end{array}$ & 0.437 & $\begin{array}{l}5.6 \% \\
\mathbf{6 . 0 \%}\end{array}$ & 0.497 & $\begin{array}{l}5.2 \% \\
5.8 \%\end{array}$ & 0.976 \\
\hline $\begin{array}{l}\text { Yes } \\
\text { No }\end{array}$ & ROE & $\begin{array}{r}19.0 \% \\
\mathbf{2 3 . 6 \%} \\
\end{array}$ & 0.958 & $\begin{array}{r}\mathbf{1 8 . 7 \%} \\
18.1 \% \\
\end{array}$ & 0.200 & $\begin{array}{l}15.9 \% \\
19.7 \%\end{array}$ & 0.802 & $\begin{array}{r}14.4 \% \\
\mathbf{1 8 . 5 \%}\end{array}$ & 0.935 \\
\hline Intangibles & & mean & $p$-value & mean & $p$-value & mean & $p$-value & mean & $p$-value \\
\hline $\begin{array}{l}\text { Yes } \\
\text { No }\end{array}$ & ROA & $\begin{array}{l}7.0 \% \\
6.8 \%\end{array}$ & 0.659 & $\begin{array}{r}6.4 \% \\
6.3 \%\end{array}$ & 0.354 & $\begin{array}{r}6.1 \% \\
4.8 \%\end{array}$ & 0.995 & $\begin{array}{l}\mathbf{5 . 8 \%} \\
4.4 \%\end{array}$ & 0.340 \\
\hline $\begin{array}{l}\text { Yes } \\
\text { No }\end{array}$ & ROE & $\begin{array}{r}21.3 \% \\
18.9 \% \\
\end{array}$ & 0.523 & $\begin{array}{r}18.4 \% \\
\mathbf{1 8 . 7 \%} \\
\end{array}$ & 0.413 & $\begin{array}{r}\mathbf{1 8 . 4 \%} \\
14.5 \%\end{array}$ & 0.848 & $\begin{array}{r}\mathbf{1 7 . 3 \%} \\
12.9 \%\end{array}$ & 0.368 \\
\hline Patents & & mean & $p$-value & mean & $p$-value & mean & $p$-value & mean & $p$-value \\
\hline $\begin{array}{l}\text { Yes } \\
\text { No }\end{array}$ & ROA & $\begin{array}{l}6.3 \% \\
7.7 \%\end{array}$ & 0.379 & $\begin{array}{r}6.6 \% \\
6.2 \%\end{array}$ & 0.589 & $\begin{array}{r}6.2 \% \\
5.3 \%\end{array}$ & 0.702 & $\begin{array}{r}6.0 \% \\
4.6 \%\end{array}$ & 0.488 \\
\hline $\begin{array}{l}\text { Yes } \\
\text { No }\end{array}$ & ROE & $\begin{array}{l}\mathbf{2 1 . 5 \%} \\
19.7 \%\end{array}$ & 0.782 & $\begin{array}{l}\mathbf{2 0 . 5 \%} \\
16.4 \%\end{array}$ & 0.119 & $\begin{array}{r}\mathbf{1 9 . 6 \%} \\
14.6 \%\end{array}$ & 0.724 & $\begin{array}{l}\mathbf{1 7 . 5 \%} \\
14.2 \%\end{array}$ & 0.451 \\
\hline Disclosure & & mean & $p$-value & mean & $p$-value & mean & $p$-value & mean & $p$-value \\
\hline $\begin{array}{l}\text { Yes } \\
\text { No }\end{array}$ & ROA & $\begin{array}{l}6.7 \% \\
7.6 \%\end{array}$ & 0.258 & $\begin{array}{l}6.9 \% \\
\mathbf{7 . 8 \%}\end{array}$ & $0.089 *$ & $\begin{array}{l}5.4 \% \\
7.6 \%\end{array}$ & 0.216 & $\begin{array}{l}5.1 \% \\
6.9 \%\end{array}$ & 0.430 \\
\hline $\begin{array}{l}\text { Yes } \\
\text { No }\end{array}$ & ROE & $\begin{array}{r}18.8 \% \\
27.7 \%\end{array}$ & 0.292 & $\begin{array}{l}17.2 \% \\
\mathbf{2 4 . 6 \%}\end{array}$ & 0.206 & $\begin{array}{r}15.9 \% \\
\mathbf{2 4 . 6 \%}\end{array}$ & 0.280 & $\begin{array}{r}14.6 \% \\
\mathbf{2 4 . 5 \%}\end{array}$ & 0.515 \\
\hline
\end{tabular}

Note: $*$ significant at the level of $10 \% ; \mathrm{ROA}=$ return on assets; ROE=return on equity.

Source: research data, 2016.

When the full sample was analyzed, the results showed that low-risk innovation, i.e. competitive advantage acquired by way of contracts and agreements (brands, know-how, intellectual property, copyrights, etc.), improved economic performance persistently in relation to non-innovative firms (Table 8), although the difference was not statistically significant, as predicted by RBV. Investment in high-risk innovation (R\&D) (Gilsing, \& Nooteboom, 2006; Kim, 2015; March, 2001;) and disclosure of innovation-related information were not associated with increased economic performance, let alone persistence, at any level.

Table 9 - Kruskal-Wallis analysis of diversification of innovation vs. mean performance in sustainable Brazilian and European firms

\begin{tabular}{lcc}
\hline Brazilian firms & mean ROA & mean ROE \\
\hline No innovation & $5.6 \%$ & $17.3 \%$ \\
One type of innovation & $6.4 \%$ & $15.4 \%$ \\
Two types of innovation & $\mathbf{7 . 7 \%}$ & $16.9 \%$ \\
Three types of innovation & $5.7 \%$ & $\mathbf{2 0 . 0 \%}$ \\
\hline $\boldsymbol{p}$-value & 0.571 & 0.695 \\
\hline European firms & mean ROA & mean ROE \\
\hline No innovation & $6.0 \%$ & $17.8 \%$ \\
One type of innovation & $4.3 \%$ & $14.6 \%$ \\
Two types of innovation & $\mathbf{6 . 6 \%}$ & $\mathbf{2 2 . 7 \%}$ \\
Three types of innovation & $5.9 \%$ & $17.5 \%$ \\
\hline $\boldsymbol{p}$-value & 0.489 & 0.994 \\
\hline Brazilian and European firms & $\mathbf{m e a n ~ R O A}$ & $\mathbf{m e a n ~ R O E}$ \\
\hline No innovation & $5.8 \%$ & $17.5 \%$ \\
One type of innovation & $5.6 \%$ & $15.1 \%$ \\
Two types of innovation & $\mathbf{6 . 9 \%}$ & $\mathbf{2 1 . 0 \%}$ \\
Three types of innovation & $5.9 \%$ & $17.8 \%$ \\
\hline $\boldsymbol{p}$-value & 0.184 & 0.130
\end{tabular}

Note: Types of innovation=R\&D, intangibles and patents.

Source: research data, 2016. 
In this study, we also analyzed the correlation between innovation and performance by considering levels of diversification of innovation in each group and in the full sample (Almahendra; Ambos, 2015; Gilsing, \& Nooteboom, 2006; Gomes, Kruglianskas, \& Scherer, 2012; Scandelari, Cunha, 2013). Baaij, Greeven and Van Dalen (2004) attribute differences in this relation to cyclical processes of creative destruction which induce the ending of prevailing persistent superior performance while enabling other firms to improve their performance and achieve persistent superior performance.

Thus, Table 9 is a comparison between diversification of innovation and mean performance.

The Kruskal-Wallis test revealed no significant differences in performance, despite the observed discrepancies (Table 9). With the exception of one scenario, mean performance increased the most in firms investing in two types of innovation, suggesting that investment in all three types of innovation concomitantly (high risk, low risk and consolidated innovation) is less efficient from the point of view of profits (ROA and ROE). Thus, firms are best served by strategies with an optimal mix of innovation activities, whether exploratory or exploitative (March, 2001), as illustrated by Almahendra and Ambos (2015), Gilsing and Nooteboom (2006), Gomes, Kruglianskas and Scherer (2012), Kim (2015) and Kruglianskas and Scherer (2012).

\section{DISCUSSION AND CONCLUSION}

The results of the present study have a number of theoretical and managerial implications which deserve a broader discussion. Many scholars have questioned the correlation between innovation and economic performance due to the scarcity of consistent evidence in the literature. According to RBV, the unique nature of innovation resources and country- and firm-level heterogeneity is the main factor determining superior and persistent performance. However, since we (and many other authors) found little evidence of a correlation between innovation and performance, we would argue that innovation types should always be considered when evaluating heterogeneity. It would seem that the impact of economic, structural and institutional factors is strong enough to mask the potential effect of innovation and other unique resources, mediating or obscuring the association posited by RBV.

Although intangible innovation involves lower risk than exploratory innovation, intangibles were essential assets in the Brazilian and European firms analyzed, suggesting superior economic performance, despite the absence of statistically significant differences. As for disclosure, the pattern was similar to that of Brazilian firms: mean economic performance was superior in firms with no disclosure.

According to Arruda, Vermulm and Hollanda (2006), Lundvall et al. (2002) and Tidd, Bessant and Pavitt (2008), firms using innovation as a strategic resource in association with sustainable management models to remain competitive have been shown to be sustainable in their respective markets. Thus, it is assumed that innovation is affected by country-specific institutional, political, social, economic and infrastructure factors (Alam, Uddin, \& Yazdifar, 2019; Rajapathirana, \& Hui, 2018).

In general, our results are compatible with those of other studies in which the relation between innovation and performance was found to be weak or negligible (Brito, Brito, \& Morganti, 2009; Carvalho, Kayo, \& Martin, 2010; Jefferson et al., 2003; Jensen, Menezes-Filho, \& Sbragia, 2004; Santos et al., 2014; Silveira, \& Oliveira, 2013; Teh, Kayo, \& Kimura, 2008). This may in part be justified by the extended time frame required for R\&D to materialize in earnings (Jensen, MenezesFilho, \& Sbragia, 2004), by the heterogeneity of the firms and the regions considered (Carvalho, Kayo, \& Martin, 2010), and by differences in know-how accumulation and appreciation of innovation (Arruda, Vermulm, \& Hollanda, 2006; Tidd, Bessant, \& Pavitt, 2008).

According to Rajapathirana and Hui (2018), investigations with a focus similar to ours provide useful insights for managers of potential and effective innovation capacities, allowing them to make 
more accurate assessments of the ability of investments in innovation to generate economic and financial gains on the Brazilian market.

Although our study failed to show a correlation between diversification of innovation and mean performance, it provided evidence of an efficiency curve determined by trade-offs in the choice of innovation activity (Almahendra, \& Ambos, 2015).

In the case of Brazilian firms, adoption of only one type of innovation produced the greatest ROA, whereas no innovation at all was associated with performance well below the curve. When ROE was used as indicator, performance only increased if a mix of $R \& D$, intangibles and patents was considered. In the absence of this option, not to invest in innovation was more profitable in relation to the average (expected) performance of the group. In the European sample, firms with no investment in innovation performed second-best, following firms with two types of innovation. Firms with only one type of innovation performed the worst on the average.

When the groups were pooled, a different scenario emerged: firms investing in innovation at all three levels performed better than firms with one type of innovation only, or with zero investment in innovation. An intermediate or high level of diversification was the best alternative, but when this was not possible, the second-most profitable option was not to invest in innovation at all. In short, the mix of innovation adopted by each firm may determine superior performance. Managers are advised to carefully evaluate the strategic demands of each competitive scenario to reach the optimal level of diversification in innovation, as explained by Gomes, Kruglianskas and Scherer (2012).

Our results support the notion expressed by RBV that firm-specific circumstances and resources can create and sustain competitive advantage and that, consequently, firms must analyze and compare different scenarios in order to maximize economic performance along a hypothetical efficiency curve. As suggested by other authors, innovation type should be considered in addition to other variables in the development of corporate strategies. The notion of suitability expounded by Barney (1991) suggests investigating beyond the mere identification of sources of competitive advantage. According to RBV, certain organizational structures are necessary for firms to exploit the potentialities of specific strategic resources. In this light, it is conceivable that certain variables can mediate the acquisition of competitive advantage.

The types of innovation considered in this study may indicate scenarios in which performance would be impacted in different ways. This is because innovation type, for example, indicates a firm's innovative efforts in terms of innovative activities, or the consolidated results of this effort, among other possibilities. The differences between economic contexts has not been sufficiently investigated since the process of know-how accumulation differs from country to country, impacting firms. In addition to these differences (and certain factors which lie outside the scope of this study), strategies related to innovation can interfere in the building of competitive advantage. One such strategy is sustainability employed as a tool for differentiation (HART, 1995). On one side, innovation meets short-term economic demands; on the other, sustainable practices meet long-term social and environmental demands while influencing the innovation process.

Brazilian and European firms did not differ as much regarding the disclosure of information on innovation as they did with regard to the other innovation variables. This result has at least two possible interpretations: i) due to the relevance attributed to this information (Gomes, Kruglianskas, \& Scherer, 2012; Gu, \& Li, 2003; Vicenti, Gomes, \& Machado, 2013), firms naturally choose to disclose it, meeting the demands of investors and stakeholders concerned about the management of strategic resources, and ii) because Brazilian firms invest relatively little in innovation, disclosure can help capture funds and mitigate discrepancies due mostly to adverse institutional and environmental factors.

In the context of sustainable Brazilian and European firms, the claim of RBV that innovation potentially translates into competitive advantage reflected in superior and persistent performance could not be validated, although highly innovative firms did perform better (non-significantly) than firms with low levels of innovation. The economic gains obtained by innovative firms were not 
substantial, relevant or persistent enough to characterize innovation as a competitive advantage. From the perspective of suitability, investment in sustainable practices is expected to create an environment favorable to the acquisition of advantages related to economic performance, since the demand for social and environmental responsibility are theoretically met, while communicating the firm's efforts in the quest for competitiveness and market consolidation.

The firms in our sample did not display superior and persistent performance attributable to innovation, perhaps because the study period was too short to capture the effects of innovation. Companies continuously invest in innovation ( $R \& D$, intangibles and patents) and disclose their progress with innovation to the market. If innovation generates benefits for firms, it may only be measurable in the long term, or it may not be detectable by the metrics adopted in our study. Innovative firms persuade stakeholders of the benefits of innovation, even if such benefits cannot be shown in the short term. Eventually, as the benefits materialize, they project the firm ahead of the competition.

Our study provides subsidies for managers looking to optimize investments in innovation, increasing the efficiency of resources and boosting differentiation. The fact that high levels of innovation do not necessarily translate into greater performance suggests there may be an ideal level of investment above which cost-efficiency is compromised. Identifying this cut-off point on the efficiency curve, where competitive advantage is acquired with minimal investment, is a challenge for managers. This view is supported by Barney (1991) with regard to the demand for adequacy in organizational structures and heterogeneity. Again, it should be pointed out that in this study the effect of innovation was evaluated only in terms of return on assets and equity; innovation can produce other types of benefits, such as intrinsic value and good standing in the eyes of potential investors and providers of capital for long-term innovation projects.

Our results also nurture the discussion about the role of accounting in socio-environmental information disclosure. The relevance of this perspective is evidenced by the political underpinnings of the development of accounting rules, especially after the adoption of international accounting standards (Palea, 2018). Indeed, as extensively documented in the literature, firms have enthusiastically turned to innovation and sustainability as a recipe for continuity and future economic gain (Abbas, \& Sağsan, 2019; Albert, 2019; Busco, \& Quattrone, 2018; Gomez-Conde, Lunkes, \& Rosa, 2018; Silvestre, \& T,îrcă 2019).

Thus, new reflections are in place regarding the informational content of disclosure, whether in the field of innovation or sustainable practices, inasmuch as market players consider such disclosure value-relevant (Gonçalves, \& Lemes, 2019; Gong, \& Wang, 2016; Jiang, \& Stark, 2013; Lys, Naughton, \& Wang, 2015; Middleton, 2015; Songur, \& Heavilin, 2017). Managers and accountants therefore play a crucial role in the generation and disclosure of strategic information to both firms and investors. Such information may be related to results, earnings, costs and expenses and may help clarify effects of innovation and sustainable practices on performance which are not evident in the current analysis.

The study was limited in some aspects. For example, the inclusion in the sample of firms from other developing economies might have yielded different results. Likewise, some types of innovation resources, such as human and intellectual capital, were not considered, but might be included in future investigations in loco. In addition, the use of statistical methods capable of analyzing variables of corporate heterogeneity could help identify mediators of the association between innovation and economic performance.

\section{REFERENCES}

Abbas, J., \& Sağsan, M. (2019). Impact of knowledge management practices on green innovation and corporate sustainable development: A structural analysis. Journal of Cleaner Production, 229, 611-620.

Alam, A., Uddin, M., \& Yazdifar, H. (2019). Institutional determinants of R\&D investment: Evidence from emerging markets. Technological Forecasting and Social Change, 138, 34-44. 
José Glauber C. dos Santos, Alessandra C. de Vasconcelos, Márcia Martins M. De Luca, Jacqueline V. Alves da Cunha

Albert, M. (2019). Sustainable Frugal Innovation-The connection between frugal innovation and sustainability. Journal of Cleaner Production, 237, 1-15.

Almahendra, R., \& Ambos, B. (2015). Exploration and exploitation: a 20-year review of evolution and reconceptualisation. International Journal of Innovation Management, 19(01), 1-31.

Arruda, M., Vermulm, R., \& Hollanda, S. (2006). Inovação tecnológica no Brasil: a indústria em busca da competitividade global. São Paulo: Anpei - Associação Nacional de Pesquisa, Desenvolvimento e Engenharia das Empresas Inovadoras.

Baaij, M., Greeven, M., \& Van Dalen, J. (2004). Persistent superior economic performance, sustainable competitive advantage, and schumpeterian innovation:: Leading established computer firms, 19542000. European Management Journal, 22(5), 517-531.

Barbieri, J. C., de Vasconcelos, I. F. G., Andreassi, T., \& de Vasconcelos, F. C. (2010). Inovação e sustentabilidade: novos modelos e proposições. Revista de Administração de Empresas, 50(2), 146154.

Barney, J. B. (1991). Firm resources and sustained competitive advantage. Journal of Management, 17, 99120.

Barney, J. B. (1996). The resource-based theory of the firm. Organization science, 7(5), 469-469.

Beato, R. S., De Souza, M. T. S., \& Dos Santos Parisotto, I. R. (2009). Rentabilidade dos Índices de Sustentabilidade Empresarial em Bolsas de Valores: um Estudo do ISE/BOVESPA. Innovation \& Management Review, 6(3), 108-127.

Bessant, J.; Tidd, J. (2009). Inovação e empreendedorismo. Porto Alegre: Bookman.

Bhandari, A., \& Javakhadze, D. (2017). Corporate social responsibility and capital allocation efficiency. Journal of Corporate Finance, 43, 354-377.

Brito, E. P. Z., Brito, L. A. L., \& Morganti, F. (2009). Inovação e o desempenho empresarial: lucro ou crescimento? Revista de Administração de Empresas, 8(1), 1-24.

Busco, C., \& Quattrone, P. (2018). Performing business and social innovation through accounting inscriptions: An introduction. Accounting, Organizations and Society, 67, 15-19.

Carvalho, A. P., \& Barbieri, J. C. (2013). Inovações Socioambientais em Cadeias de Suprimento: um Estudo de Caso sobre o Papel da Empresa Focal. Revista de Administração e Inovação, 10(1), 232-256.

Carvalho, F. M., Kayo, E. K., \& Martin, D. M. L. (2010). Tangibilidade e Intangibilidade na Determinação do Desempenho Persistente de Firmas Brasileiras. Revista de Administração Contemporânea, 14(5), 871-889.

Chauvin, K. W., \& Hirschey, M. (1993). Advertising, R\&D Expenditures and the Market Value of the Firm. Financial Management, 128-140.

Chen, H. H. (2008). Measuring intellectual capital using fuzzy analytic hierarchy process. International Journal of Innovation and Learning, 6(1), 51-61.

Deng, Z., Lev, B., \& Narin, F. (1999). Science and technology as predictors of stock performance. Financial Analysts Journal, 55(3), 20-32.

Ding, Y., Entwistle, G., \& Stolowy, H. (2004). International differences in research and development reporting practices: A French and Canadian comparison. Advances in International Accounting, 17, $55-72$.

Floriani, R., Beuren, I. M., \& Hein, N. (2010). Análise comparativa da evidenciação de aspectos de inovações em empresas construtoras e multisetoriais. Journal of Information Systems and Technology Management, 7(3), 693-711.

Freeman, C., \& Soete, L. (2008). A economia da inovação industrial. Campinas: Editora Campinas.

Gilsing, V., \& Nooteboom, B. (2006). Exploration and exploitation in innovation systems: The case of pharmaceutical biotechnology. Research Policy, 35(1), 1-23.

Gomes, C. M., Kruglianskas, I., \& Scherer, F. L. (2012). The influence of the management of information sources on the innovation performance of large and small businesses. International Journal of Innovation Management, 16(02), 1250012.

Gomes, C. M., Kruglianskas, I., Júnior, F. H., \& Scherer, F. L. (2009). Gestão da inovação tecnológica para o desenvolvimento sustentável em empresas internacionalizadas. Gestão \& Regionalidade, 25(73), $35-47$.

Gomes, C. M., Scherer, F. L., Menezes, U. G., Luz Neto, R., \& Kruglianskas, I. (2013). Strategies of sustainable management and business performance: an analysis in innovative companies.

International Journal of Innovation Management, 17(05), 1-31. 
Gomez-Conde, J., Lunkes, R. J., \& Rosa, F. S. (2019). Environmental innovation practices and operational performance. The joint effects of management accounting and control systems and environmental training. Accounting, Auditing \& Accountability Journal, 32(5), 1325-1357.

Gonçalves, W. D. B., \& Lemes, S. (2018). A Relação dos Gastos com P\&D com a Qualidade da Informação Contábil. Contabilidade Vista \& Revista, 29(2), 68-95.

González-Benito, J., \& González-Benito, Ó. (2006). A review of determinant factors of environmental proactivity. Business Strategy and the Environment, 15(2), 87-102.

Gu, F., \& Li, J. Q. (2003). Disclosure of innovation activities by high-technology firms. Asia-Pacific Journal of Accounting \& Economics, 10(2), 143-172.

Hackston, D., \& Milne, M. J. (1996). Some determinants of social and environmental disclosures in New Zealand companies. Accounting, Auditing \& Accountability Journal, 9(1), 77-108.

Hart, S. L. (1995). A natural-resource-based view of the firm. Academy of management review, 20(4), 986-1014.

Heikkurinen, P., \& Bonnedahl, K. J. (2013). Corporate responsibility for sustainable development: a review and conceptual comparison of market-and stakeholder-oriented strategies. Journal of Cleaner Production, 43, 191-198.

Jefferson, G., Albert, G. Z., Xiaojing, G., \& Xiaoyun, Y. (2003). Ownership, performance, and innovation in China's large-and medium-size industrial enterprise sector. China Economic Review, 14(1), 89-113.

Jensen, J., Menezes-Filho, N., \& Sbragia, R. (2004). Os determinantes dos gastos em P\&D no Brasil: uma análise com dados em painel. Estudos Econômicos (São Paulo), 34(4), 661-691.

Jiang, W., \& Stark, A. W. (2013). Dividends, research and development expenditures, and the value relevance of book value for UK loss-making firms. The British Accounting Review, 45(2), 112-124.

Kayo, E. K., Teh, C. C., \& Basso, L. F. C. (2006). Ativos intangíveis e estrutura de capital: a influência das marcas e patentes sobre o endividamento. Revista de Administração da USP, 41(2), 158-168.

Khurana, S., Haleem, A., \& Mannan, B. (2019). Determinants for integration of sustainability with innovation for Indian manufacturing enterprises: Empirical evidence in MSMEs. Journal of Cleaner Production, 229, 374-386.

Kim, Y. (2015). Environmental, sustainable behaviors and innovation of firms during the financial crisis. Business Strategy and the Environment, 24(1), 58-72.

Lee, R. P., \& Chen, Q. (2009). The immediate impact of new product introductions on stock price: the role of firm resources and size. Journal of Product Innovation Management, 26(1), 97-107.

Lev, B. (2001). Intangibles: management, measurement, and reporting. Washington: Brookings Institution Press.

Lundvall, B. Å., Johnson, B., Andersen, E. S., \& Dalum, B. (2002). National systems of production, innovation and competence building. Research policy, 31(2), 213-231.

Lys, T., Naughton, J. P., \& Wang, C. (2015). Signaling through corporate accountability reporting. Journal of Accounting and Economics, 60(1), 56-72.

Machado, M. A. V., \& Machado, M. R. (2013). Responsabilidade social impacta o desempenho financeiro das empresas? Advances in Scientific and Applied Accounting, 4(1), 2-23.

Madorran, C., \& Garcia, T. (2016). Corporate social responsibility and financial performance: the Spanish case. Revista de Administração de Empresas, 56(1), 20-28.

March, J. G. (1991). Exploration and exploitation in organizational learning. Organization Science, 2(1), 71-87.

Marqués, D. P., Simón, F. J. G., \& Carañana, C. D. (2006). The effect of innovation on intellectual capital: an empirical evaluation in the biotechnology and telecommunications industries. International Journal of Innovation Management, 10(01), 89-112.

Matitz, Q. R. S., \& Bulgacov, S. (2011). O conceito desempenho em estudos organizacionais e estratégia: um modelo de análise multidimensional. Revista de Administração Contemporânea, 15(4), 580607.

Megna, P., \& Klock, M. (1993). The impact of intangible capital on Tobin's q in the semiconductor industry. The American Economic Review, 83(2), 265-269.

Middleton, A. (2015). Value relevance of firms' integral environmental performance: Evidence from Russia. Journal of Accounting and Public Policy, 34(2), 204-211.

Moura, P. G., \& Galina, S. V. (2009). Empresas multinacionais de origem brasileira e a publicação internacional de patentes. Innovation \& Management Review, 6(3), 26-45. 
José Glauber C. dos Santos, Alessandra C. de Vasconcelos, Márcia Martins M. De Luca, Jacqueline V. Alves da Cunha

Nekhili, M., Boubaker, S., \& Lakhal, F. (2012). Ownership structure, voluntary R\&D disclosure and market value of firms: the French case. International Journal of Business, 17(2), 126.

Organization for Economic Co-operation and Development. (2005). Oslo manual: guidelines for collecting and interpreting innovation data. 3a ed. Paris: OECD, Eurostat.

Organization for Economic Co-operation and Development. (2018). Oslo manual 2018: guidelines for collecting, reporting and using data on innovation. 4th Edition. The measurement of scientific, technological and innovation activities, OECD. Paris: OECD, Eurostat.

Palea, V. (2018). Financial reporting for sustainable development: critical insights into IFRS implementation in the European Union. Accounting Forum, 42, 248-260.

Pätäri, S., Arminen, H., Tuppura, A., \& Jantunen, A. (2014). Competitive and responsible? The relationship between corporate social and financial performance in the energy sector. Renewable and Sustainable Energy Reviews, 37, 142-154.

Perez, M. M., \& Famá, R. (2006). Ativos intangíveis e o desempenho empresarial. Revista Contabilidade \& Finanças, 17(40), 7-24.

Peteraf, M. A. (1993). The cornerstones of competitive advantage: a resource-based view. Strategic Management Journal, 14(3), 179-191.

Pippel, G. (2015). R\&D collaboration for environmental innovation. International Journal of Innovation Management, 19(1) 1-22.

Póvoa, L. M. C. (2010). A universidade deve patentear suas invenções? Revista Brasileira de Inovação, 9(2), 231-256.

Priem, R. L., \& Butler, J. E. (2001). Is the resource-based "view" a useful perspective for strategic management research? Academy of Management Review, 26(1), 22-40.

Rajapathirana, R. J., \& Hui, Y. (2018). Relationship between innovation capability, innovation type, and firm performance. Journal of Innovation \& Knowledge, 3(1), 44-55.

Rogers, M. (1998). The definition and measurement of innovation. [Working Paper, n. 10/98.]. Melbourne Institute, Parkville, Australia.

Saeidi, S. P., Sofian, S., Saeidi, P., Saeidi, S. P., \& Saaeidi, S. A. (2015). How does corporate social responsibility contribute to firm financial performance? The mediating role of competitive advantage, reputation, and customer satisfaction. Journal of Business Research, 68(2), 341-350.

Salimi, N., \& Rezaei, J. (2018). Evaluating firms' R\&D performance using best worst method. Evaluation and Program Planning, 66, 147-155.

Samad, S. (2012). The influence of innovation and transformational leadership on organizational performance. Procedia-Social and Behavioral Sciences, 57, 486-493.

Santos, D. F. L. (2012). O perfil da inovação na indústria brasileira. Revista Gestão Industrial, 8(3).

Santos, D. F. L., Basso, L. F. C., Kimura, H., \& Kayo, E. K. (2014). Innovation efforts and performances of Brazilian firms. Journal of Business Research, 67(4), 527-535.

Santos, P. M. F., \& Porto, R. B. (2013). A gestão ambiental como fonte de vantagem competitiva sustentável: contribuições da visão baseada em recursos e da teoria institucional. Revista de Ciências da Administração, 15(35), 152-167.

Scandelari, V. D. R. N., \& da Cunha, J. C. (2013). Ambidestralidade e desempenho socioambiental de empresas do setor eletroeletrônico. Revista de Administração de Empresas, 53(2), 183-198.

Schumpeter, J. A. (1988). Teoria do desenvolvimento econômico: uma investigação sobre lucros, capital, crédito, juro e o ciclo econômico. 3a ed. São Paulo: Nova Cultural.

Silva, C. D. F., \& Suzigan, W. (2014). Padrões setoriais de inovação da indústria de transformação brasileira. Estudos Econômicos, 44(2), 277-321.

Silveira, J. D. C. D. A., \& Oliveira, M. A. (2013). Inovação e desempenho organizacional: um estudo com empresas brasileiras inovadoras. Sociedade, Contabilidade e Gestão, 8(2).

Silvestre, B. S., \& Tîrrcă, D. M. (2019). Innovations for sustainable development: Moving toward a sustainable future. Journal of Cleaner Production, 208, 325-332.

Songur, H., \& Heavilin, J. E. (2017). Abnormal research and development investments and stock returns.

The North American Journal of Economics and Finance, 42, 237-249.

Teh, C. C., Kayo, E. K., \& Kimura, H. (2008). Marcas, patentes e criação de valor. Revista de Administração Mackenzie, 9(1). 
Teigland, R., Fey, C. F., \& Birkinshaw, J. (2000). Knowledge dissemination in global R\&D operations: an empirical study of multinationals in the high technology electronics industry. Management International Review, 49-77.

Tidd, J., Bessant, J., \& Pavitt, K. (2008). Gestão da inovação. 3a ed. Porto Alegre: Bookman.

Vicenti, T., Gomes, G., \& Machado, D. D. P. N. (2013). Evidenciação das Inovações em Empresas de Alimentos Processados Listadas na BM\&FBOVESPA. Revista Gestão \& Tecnologia, 13(1), 22-50 Wernerfelt, B. (1984). A resource-based view of the firm. Strategic Management Journal, 5(2), 171-180. 